Pandermite (C. G. Warnford Lock, Jour. Soc. Arts, Aug. 6. 1880). -This is a hydrous borate of lime occurring in considerable quantity over a large area near the port of Panderma on the Asiatic shore of the Sea of Murmora. "It occurs in a stratum at the bottom of an enormous bed of gypsum-has been proved for a vertical distance of 45 feet. The mineral exists in closely packed nodules, of very irregular size and shape, and of all weights up to a ton.... In outward appearance it closely resembles a snowghite fine-grained marble."

J. H. C.

\title{
(B) bituany.
}

Henry Luduam.-Again we have to record the loss of an original member of the Mineralogical Society, in the person of Mr. Henry Ludlam, F.G.S., who died on the 23 rd of June, at the age of 58 .

Early a student of the natural sciences, that of Mineralogy became his favourite subject, in which he was greatly assisted by the study of chemistry, which occupied many of the leisure evening hours which the care of an important business allowed him. Aided by an unusually critical judgment he gathered together a large and valuable collection of mineruls in which some of the specics were conspicuous for their perfection of crystalline form. To these he subsequently added the well-known and important collection which belonged to the late Mr. Charles Hampden Turner, of Rooksnest, Surrey; and also that made by the late Mr. Willian Nevill, F.G.S., of Godalming. The whole forms certainly the most complete and probably the finest collection of minerals ever made by a private collector. It is now the property of the nation, having been left to the Museum of Practical Geology, Jermyn Street, London.

But Mr. Iudlam was not the mere collector. He had long had in view the desirability of preparing a complete descriptive and crystallographic catalogue of that which it had been his good fortnne to accumnlate. This great work, to which he looked forward as to a labour of love, was actually commenced by him shortly before the illness which ended in his premature death. The science of mineralogy has thus lost an earnest worker, while his personal friends have to lament the loss of a warm-hearted and true English gentleman.

T. D.

W. W. Stoddart, F.G.S., F.C.S., F.I.C., \&c., Public Analyst for the city und county of Bristol and the county of Gloucester, died of heart disease at his residence, Sneyd Park, Bristol, on the 30th of May last, aged 57. Mr. Stoddart was one of the original members of this society, and he contributed a paper, " on the occurrence of Celestine in tho Keuper marls, and its influcnce on the composition of plants"-to the first number of the Mineralogical Magazine.

J. H. C. 